\title{
Seyahat Acentası Enformasyon Sistem Başarısının Kullanıcı Perspektifinden İncelenmesi
}

\author{
Evaluating Travel Agency Information System Success from the User's Perspective
}

\section{Songül ÖZCAN * Beykan ÇIZZEL **}

$\ddot{O}_{z:}$ Turizm endüstrisinde enformasyon sistemlerinin kullanımı giderek yaygınlaşmaktadır. Günümüzde enformasyon sistemleri turizm işletmeleri için rekabette önemli bir araç haline gelmiştir. Turizmin tüm sektörlerinde olduğu gibi seyahat aracılarında da kullanılan enformasyon sistemlerinin geliştirilmesinde, kullanıcıların beklentileri ve sistem hakkındaki performans değerlendirmeleri büyük önem taşımaktadır. $\mathrm{Bu}$ çalışmanın amacı, seyahat acentalarında kulalanılan enformasyon sistemlerinin başarısını kullanıcı bakış açısından incelemektir. $\mathrm{Bu}$ amaçla ilk olarak ilgili literatür taraması ve konunun uzmanları ile yapılan görüşmeler doğrultusunda enformasyon sistem başarısının kullanıcı perspektifinden değerlendirilmesine yönelik bir ölçüm aracı geliştirilmiştir. Sonrasında 390 enformasyon sistemi kullanıcısına uygulanan anket ile veriler toplanarak yapılan önem-performans analizi yöntemi ile seyahat acentalarında enformasyon sistem kullanıcılarının sistem kalitesi, enformasyon kalitesi ve hizmet kalitesine (bilişim firmasının sağladığ 1 destek hizmeti) yönelik niteliklere verdikleri önem ve bu unsurların performansı değerlendirilmiştir. Araştırma sonuçlarına göre kullanıcılar için seyahat acentası enformasyon sistem başarısında en önemli faktörün sistemi geliştiren bilişim firmasının sağladığı destek hizmeti kalitesi olduğu tespit edilmiştir. Bu nedenle çalışmamızda yer alan analiz sonuçları sistemi geliştiren teknoloji firmaları ve kullanıcılar açısından önemli ipuçları sunmaktadır.

Anahtar sözcükler: Turizm, Seyahat Acentaları, Enformasyon Sistemleri, Enformasyon Sistemleri Başarı Modelleri, Önem-Performans Analizi (ÖPA)

\begin{abstract}
The use of information systems in the tourism industry is becoming widespread. Information systems have for tourism enterprises become an important tool in competition. As in all sectors of tourism, the expectations of the users and performance evaluations about the system are of great importance in the development of information systems used by travel agents. The aim of this study is to examine the success of information systems used in travel agencies from the user perspective. For this purpose, firstly, a measurement tool has been developed to evaluate information system success from the user perspective in line with the literature review and interviews with experts. Then data was collected by means of a questionnaire applied to 390 of the information system users and the importance-performance analysis method was used to evaluate the importance of the information system users in the travel agencies regarding the system quality, information quality and service quality (support service provided by the IT company) and the performance of these elements. According to the results of this research, it was determined that the most important factor in the success of the information system used in travel agencies for the users is the quality of the support service provided by the IT company. The results of the analysis provide important clues for technology companies that develop the system.
\end{abstract}

Keywords: Tourism, Travel Agencies, Information Systems, Information Systems Success Models, Importance-Performance Analysis (IPA)

\footnotetext{
* Akdeniz Üniversitesi, Turizm İşletmeciliği, Antalya. songulozcan@gmail.com, https://orcid.org/0000-0002-1825-7213

** Prof. Dr., Akdeniz Üniversitesi, Turizm Fakültesi, Antalya. beykan@akdeniz.edu.tr, https://orcid.org/0000-00030474-9222
} 


\section{Giriş}

Enformasyon Sistemleri, seyahat acentalarının turizm faaliyetlerine yönelik olarak ihtiyaç duydukları veri kayıt sistemini ve operasyona yönelik uygulamaları bünyesinde taşıyarak bir seyahat acentasında turizm hizmetinin verilmesinde ve hizmet kalitesinin sağlanmasında önemli bir potansiyele sahiptir. Seyahat işletmelerinde enformasyon sistemleri operasyon (kontratlama, rezervasyon, araç operasyonu, tur operasyonu, muhasebe vb işlemlerde) ve karar destek sistemleri (ürün geliştirme, talep tahminleme vb.) olarak yaygın kullanılmaktadırlar. Seyahat acentaları enformasyon sistemlerine yatırım yaparken fayda maliyet analizi yapmak ve yatırımın geri dönüşünü hesaplamak zorundadırlar. Diğer taraftan seyahat acentalarında kullanılan enformasyon sistemlerinin başarısının ve performansının müşteriler ve kullanıcılar tarafından değerlendirilmesi, bu sistemlerin geliştirilmesi için büyük önem taşımaktadır (Çizel 2005; Akgün 2012).

Enformasyon sistem başarısının değerlendirilmesi ile ilgili alan literatür incelendiğinde araştırmacıların enformasyon sistemleri başarısını değerlendirmek için pek çok model üzerinde çalıştıkları görülmektedir. ES başarısı ölçülürken hesaba katılması gereken çok sayıda faktör vardır ve buradaki en önemli konulardan birisi sistem kullanıcılarının sistem başarısı için önem verdiği hususların ortaya konulmasıdır (DeLone \& McLean 2016). Bu çalışmanın amacı seyahat acentalarında kullanılan enformasyon sistemlerinin başarısının sistem kullanıcıları bakış açısından analiz etmektir. $\mathrm{Bu}$ amaçla önem-performans analizi yöntemi ile seyahat acentalarında enformasyon sistem kullanıcılarının sistem kalitesi, enformasyon kalitesi ve hizmet kalitesine (bilişim firmasının sağladığı destek hizmeti) yönelik niteliklere verdikleri önem ve bu unsurların performansı değerlendirilmiştir.

Çalışma iki bölümden oluşmaktadır. İlk bölümünde veri, enformasyon ve bilgi kavramları tanımlanmış ve enformasyon sistem başarısı ve performansı ile ilgili literatür taramasına yer verilmiştir. Çalışmanın ikinci bölümünde ise enformasyon sistemlerinin başarısının sistem kullanıcıları bakış açısından incelenmesine yönelik araştırma ve bulguları yer almaktadır. Çalışmanın son bölümünde ise araştırmada elde edilen bulgular ilgili literatür desteği ile tartışılmış ve yorumlanmıştır.

Günümüzde enformasyon sistemleri kullanımı rekabet avantajı sağlamak isteyen işletmeler için vazgeçilmez bir değer haline gelmiştir. Ekonomik durgunluk hatta gerileme dönemlerinde bile farklı alanlardaki pek çok şirket enformasyon teknolojisine yatırım yapmaya devam etmektedir. Yatırımlar karmaşık ve yüksek maliyeti olsa da değer yaratmak için gereklidirler. İşletmelerin enformasyon sistemleri için yaptıkları harcamaların bütçe içindeki miktarı diğer giderlerden çok yüksek olabilmektedir. Dolayısı ile bu büyük yatırımların yapılabilmesi için firma yöneticilerinin yaptıkları bu harcama kaleminin işletmeye faydasını net bir şekilde görebilmeleri, özellikle yöneticilerin şirket bütününe yansıyan bu faydaları anlamaları gerekmektedir. Ekonomik faktörleri tamamen göz ardı etmeyen ve diğer şirketler ile kıyasıya bir yarış içinde bulunan işletmeler karşıllğını alamayacakları bir yatırım yapmak istemezler ve yaptıkları ES yatırımlarının başarılarını bilmek ve takip etmek eğilimindedirler. Enformasyon sistemleri başarılarını izlemek hem şirketin hem de şirkette çalışanların üretkenliğe, etkililiğe, ürünlerin ve yapılan işin kalitesine ve işletmelerin rekabetçi yapısına katkılarını anlamına geldiğini söylemek mümkündür. Bu bağlamda, bu çalışmanın amacı seyahat acentalarında kullanılan enformasyon sistemlerinin başarısını kullanıcı bakış açısından incelemektir. Önem-performans analizi yöntemi ile seyahat acentalarında enformasyon sistem kullanıcılarının sistem kalitesi, enformasyon kalitesi ve hizmet kalitesine (bilişim firmasının sağladığı destek hizmeti) yönelik niteliklere verdikleri önem ve bu unsurların performansı değerlendirilmiştir. 


\section{Literatür Taraması}

Enformasyon sistemleri, DeLone \& McLean'a göre; bir organizasyon içinde operasyonları, süreçleri, yönetim analizlerini ve karar verme fonksiyonlarını destekleyecek bilgiyi sağlamak üzere entegre edilmiş olan sistemler olarak tanımlanmıştır. Buna göre ES başarısı organizasyonun, kullanıcıların ve teknik destek personelinin gereksinim duyduğu içerikleri karşılaması ile ilişkilidir. Enformasyon sistemleri başarısı işletmenin kendisine hedef olarak belirlediği işleri başarma seviyesidir. Enformasyon sistemleri ölçülerek bu sistemlere yapılan yatırımın geri dönüşü değerlendirilir, enformasyon sistemlerinin etkinliği ve faydası saptanır (DeLone \& McLean 2003; DeLone \& McLean 2016).

İşletmeler enformasyon sistemlerine kuruluş üzerinde olumlu etkilerini umarak büyük yatırımlar yaparlar. Karmaşık ve maliyetli olabilen çağdaş enformasyon sistemi yatırımları değerlerini haklı göstermek için artan bir inceleme ve baskı altındadırlar (Markus et al., 2003).

Sistem kullanıcıları sistemin başarısını değerlendirirken; sistemden elde ettikleri verilerin yararlılı̆̆ı, sistemin düşük maliyetli oluşu ve sistemin ileri teknolojiyi yüksek kalitede sunması kriterlerini dikkate alırlar. Eğer sistem bu özellikleri taşıyorsa bu sistem başarılıdır. Bir başka tanıma göre ise enformasyon sistemleri etkinliği, sistemin çıktısı olarak üretilen bilginin gerçekliği ve bu bilgilerin izlenmesi ve takip edilmesi ile ilgili yönetimdeki karar vericilerin tatmini olarak açıklanmaktadır (Özkan 2005; 2006). Enformasyon sistemleri başarısının ölçümünde tek bir model değil pek çok model bulunmaktadır (Seddon et al. 2002). Enformasyon Sistemlerinin başarısını ölçmek için çeşitli ölçeklerin kullanıldığı görülmektedir. Bu alanda yapılan çalışmalara liderlik eden ve diğer çalışmalara temel oluşturan DeLone \& McLean'in enformasyon sistemleri başarı modelidir (DeLone \& McLean 1992).

Enformasyon sistemleri etkinliği konusunda birçok çalışma yapılmıştır. Bu çalışmalarda enformasyon sistemleri başarısı gibi bağımlı değişkenin tespit edilmesi en zor konulardan olmuştur. Farklı araştırmacılara göre başarının farklı yönlerini ele almak, karşılaştırmalar yapmak ve enformasyon sistemleri araştırması için kümülatif bir gelenek inşa etme olasılığı zordur. "ES Başarısı" kavramı, "ES Etkinliği" ve "ES Kalitesi" nin gelişmekte olan bir konsepti olarak düşünülebilir (Özkan \& Bilgen 2003).

Araştırmacılar ve uygulayıcılar için enformasyon sistemlerinin başarısının değerlendirilmesi zorluklar içerir. Enformasyon teknolojisinin sürekli değişen rolü ve enformasyon teknolojisinin kullanımına bağlı olarak yönetilen enformasyon sistemleri başarısı ölçümü kavramının karmaşık olması muhtemel sebepler arasında sayılabilir (DeLone \& McLean 2016). Enformasyon sistem başarısını açıklayan birçok model vardır. Bunlardan en çok kullanılanları Davis'in Teknoloji Kabul Modeli (1989) ile DeLone \& McLean'ın ES başarı modeli $(1992,2003)$ olmuştur.

Davis tarafından 1986 da tanıtılan, Teknoloji Kabul Modeli (TKM) bilgisayar kullanımının kabul edilmesinin çeşitli faktörlerinin belirli kullanıcı davranışları ile ilişkili olduğunu açıklamaktadır. Teknoloji Kabul Modeli, kullanıcıların yeni bir enformasyon sistemi kullanmaya başlayacakları zaman algılanan yararlılık ve algılanan kullanım kolaylığı faktörlerinin bu yeni sistemi nasıl ve ne zaman kullanacaklarını etkilediğini öne sürmektedir (Davis 1989) Yıllar boyunca enformasyon sistemleri başarısını inceleyen çok sayıda çalışmada, DeLone ve McLean'ın $(1992,2003)$ Başarı Modeli enformasyon sistemleri literatüründe yer alan en kapsamlı enformasyon sistemi değerlendirme modeli olarak kabul edilmektedir (Petter ve diğerleri, (2008). Chen \& Cheng (2009), yaptıkları çalışmada tüketicilerin çevrimiçi alışveriş yapma niyetini tahmin etmek için başarı modelini benimsemişlerdir. Elliot, Li \& Choi (2013), web sitelerinin kullanıcıda alışkanlık yapan özelliklerini ve sanal seyahat topluluklarında web sayfasında işlem yapma niyetini incelemek için başarı modelini uygulamışlardır. Mobil cihazların giderek artması mobil uygulamaların da akademik çalışmalara girmesine yol açmıştır. Yapılan bazı 
çalışmalarda araştırmacılar başarı modelini mobil kullanıcı davranışını anlamak içinde kullanılmışlardır (Chen \& Lan, 2014). Morosan 2014 yılındaki çalışmasında mobil ağlar hacker saldırısına ve bilgi müdahalesine karşı daha savunmasız olabilir mi sorusunu araştırmıştır. Diğer bazı araştırmacılar çeşitli bilgi sistemlerinin başarısını daha iyi anlamak için Delone \& McLean başarı modelini kısmen ve tamamen adapte etmişlerdir (Lwoga, 2014; Marjanovic et al. 2016; Cidral et al., 2018).

Gable ve Sedera (2008) birlikte yaptıkları çalışmalarında DeLone \&McLean (2003) modelini temel alan ES-Etki Modelini tanıtmışlardır. Bu modelde Delone \&McLean (1992) tarafından tanımlanan orijinal modeldeki boyutlar kullanılarak veya sistem kalite literatür derlemeleri yaparak sistem kalitesinin endekslerini oluşturmuşlardır. Enformasyon Sistemlerinin başarısını tanımlamak için çok fazla araştırma yapılmıştır. ES başarısının karmaşık, birbirine bağlı ve çok boyutlu doğası nedeniyle zorluklar içermektedir. Bu konuya değinmek için, DeLone \& McLean (1992), 1981-1990 döneminde yayınlanan araştırmaları gözden geçirmiş ve ES başarısının bir sınıflandırmasını oluşturmuşlardır (DeLone \& McLean 2016). DeLone ve McLean (1992), bilgi sistemi başarısını tanımlayan altı ana değişken önermişlerdir: Sistem Kalitesi, Enformasyon Kalitesi, Kullanım, Kullanıcı Memnuniyeti, Bireysel Etki ve Örgütsel Etki. Model değişkenler arasındaki süreç ilişkilerinden ziyade nedensellik önermektedir. Örneğin, daha yüksek sistem kalitesi, kullanıcı memnuniyetini ve kullanımını artırır.

$\mathrm{Bu}$ araştırma kapsamında ES başarısını ölçmek için DeLone \& McLean, 2002 yılında tanımladığı modeldeki üç değişken (enformasyon kalitesi, sistem kalitesi ve servis kalitesi) kullanılmıştır. Bunun en temel sebebi DeLone \& McLean modeli, enformasyon sistemlerinin başarısı hakkında kapsamlı bir çalışma alanı sunmakta ve zengin ama karışık bir yapıya sahip olan enformasyon sistemlerini daha anlaşlabilir bir bütün haline getirmektedir. Sistem kalitesi sisteme erişimin kolaylığı, sistemin bütünleşmiş olması, sistemin kullanıcıların problemlerine ve ihtiyaçlarına cevap verme süresi, kullanıcıların zihinlerinde oluşturdukları beklentileri karşılama seviyesi, sistemi kullanım kolaylığı, sistemin güvenli olması, sistemin anlaşılması ve sisteme adapte olunması gibi maddelerden oluşur (Ultav 2010). DeLone \& McLean (1992) bir enformasyon sisteminden arzulanan temel karakteristik özellik olarak; kullanıcılara karar verme aşamasında yardımcı olmak üzere kullanabilecekleri doğru bilgileri üretmesi kapsamında "Sistem Kalitesini” önermişlerdir. Sistem Kalitesi enformasyon sistemlerinin kullanıcılar tarafindan cazip bulunan karakteristik özelliklerini ifade eder ve ölçümü genel olarak bir sistemin taşımış olduğu kendisine ait bazı özellikler üzerinden yapılır. Örneğin kullanım kolaylığı, fonksiyonelliği, güvenilirliğii, esnekliği, gibi kriterler değerlendirmeye alınır. Sistem kalitesinin önemli özellikleri arasında; kullanılabilirlik, müsaitlik, güvenilirlik, uyumluluk, sistem esnekliği, sistem güvenilirliği, işlevsellik ve öğrenme kolaylı̆̆ 1 sayılabilir. Sistem kalitesi içerdiği diğer sistem özellikleri ayrıca; sezgisellik, sofistike oluş, esneklik ve tepki süreleridir (Petter et al. 2008). Sistem kalitesini ölçmek için diğer yapılar taşınabilirlik, ekonomi, sürdürülebilirlik, doğrulanabilirlik, ăg altyapısı güvenilirliği, kararlılık ve kullanıcı dostu arayüzleri içerir. Algılanan kullanım kolaylığı, sistem kalitesinin en yaygın ölçüsüdür bu konu özellikle Teknoloji Kabul Modeli araştırmalarında pek çok kere incelenmiştir (Davis 1989). Bununla birlikte daha önce belirtildiği gibi, algılanan kullanım kolaylığı bir bütün olarak sistem kalite yapısını yakalamamaktadır. Diğer araştırmacılar DeLone \& McLean (1992) tarafından tanımlanan orijinal modeldeki boyutları kullanılarak veya sistem kalite literatür derlemeleri yaparak sistem kalitesinin endekslerini oluşturmuşlardır (Gable et al. 2003).

Enformasyon kalitesi, kullanıcının sistemle olan iletişimini doğrudan etkileyen ve bu yüzden sistem üzerindeki kullanıcının tatminini ve kullanıcının sistemi kullanma eğilimini etkileyen bir kriterdir. Shannon ve Weaver 1949'da yaptıkları araştırmada enformasyon kalitesinin anlamsal enformasyon düzeyine ait olduğunu ve alıcının anlamının gönderenin amaçlanan 
anlamından daha fazla yorumlanmasıyla daha ilgili olduğunu belirtmiştir. DeLone \& McLean'a (2003) göre en yaygın enformasyon kalitesi ölçüleri; güncellik, eksiksizlik, tutarlılık, anlaşılabilirlik, doğruluk ve ilgililiktir.

Geleneksel bir enformasyon sistemi anlayışında, enformasyon kalitesi verilerin nasıl oluşturulduğuna ve kuruluş içinde nasıl kullanıldığına bağlıdır. Farklı çalışmalarda önemli ampirik araştırmalar yapılarak enformasyon kalitesi ölçülmüştür. Rai et al. (2002), enformasyon kalitesinin içerik ve formatla ilgili olduğunu öne sürmektedir. Doll \& Torkzadeh (1988) önerdiği ölçüm aracında doğruluk, içerik, format ve zamanlılık ölçümleri yer almıştır. E-ticaret sistemlerinin başarısını ölçmek için, DeLone \& McLean (2003), anlama, kişiselleștirme ve güvenlik kolaylığının ek özelliklerini önermektedir. Enformasyon kalitesinin en yaygın boyutu, genellikle hata sayısı, yani bir veritabanında tanımlandığ 1 gibi doğruluktur. Enformasyon sistemlerinin yararlanıcıları genellikle işlem yapmada ve karar verme süreçlerinde kendilerine yararlı olacak anlamlı verilerin mevcut olmasinı talep etmektedirler (Pitt et al. 1995, 173-174). DeLone \& McLean (2003) hizmet kalitesini, bu desteğin dahili bir bilgi işlem departmanı, yeni bir organizasyon birimi veya bir Internet Servis Sağlayıcısına yaptırılmış olup olmadığına bakılmaksızın bir servis sağlayıcı tarafından sağlanan genel destek olarak tanımlamaktadır. Diğer hizmet kalitesi ölçümleri arasında hızlı yanıt verme, güvence, empati, takip servisi ve teknik destek yer almaktadır (Parasuraman et al. 1988; Pitt et al. 1995).

Çalışmamızda kullandığımız Önem- Performans analiz yöntemi de pek çok araştırmacı tarafından kullanılan bir ölçüm aracı olmuştur.

\section{Önem-Performans Analizi}

Kaliteli bir hizmet sunumuyla tüketicilerin memnun edilebilmesi için, onların gerçek ihtiyaç ve beklentileri sağlıklı bir biçimde tespit edilmelidir. Her sektörde uzun vadeli başarının yakalanabilmesi için tüketicilerin gerçekte neleri arzu edip neleri arzu etmedikleri net bir şekilde anlaşımalıdır. Bu çaba, hizmet sunucusunun ana görevlerinden biridir (Hema \& Samuel 2011, 52). Tüketicilerin gerçekte ne istediğinin tespiti ve bu isteklerinin önemlilik derecelerinin sıralanması, aslında önem-performans analizinin özünü teşkil etmektedir. Literatürde ilgili çalışmalar incelendiğinde hizmet kalitesi ölçümü ile ilgili çeşitli değerlendirme metotları vardır ve pekçok araştırmacının çalışmalarında kullanılmaktadır. Bu yöntemlerden bir tanesi de Martilla \& James (1977) tarafından geliştirilen "önem-performans analizi"dir. ÖPA yapısı itibariyle basit ve kolay uygulanabilir bir teknik olduğundan, farklı alan araştırmacıları tarafından yoğun ilgi görmüş ve birçok çalışmada kullanılmıştır. Hizmet kalitesi ölçümü için Ennew, Reed \& Binks, 1993 araştırmas1, seyahat ve turizm sektöründe Evans \& Chon,1989, eğitim hizmetlerinde Alberty \& Mihalik 1989; Ortinau, Bush, Bush \& Twible 1989), sağlık hizmetlerinde (Dolinsky 1991; Hawes \& Rao 1985), eğlence ve rekreasyon hizmetlerinde (Hollenhorst, Olson \& Fortney 1992), ve bankac1lık hizmetleri Joseph et al. 2005 gibi alanlarda da uygulanan bir yöntem konumuna gelmiştir. Yakın tarihlerde Türkçe literatürde destinasyon yönetimi (Albayrak \& Caber 2011), üçüncü yaş turizmi (Cengiz \& Kantarc1 2013) konularında yapılan çalışmalar da mevcuttur. ÖPA, Turizm sektöründe de bir stratejik plan çalışmasına rehberlik edebilecek yapıda olup, eldeki firsatların tanımlanması için kullanmaya son derece müsait bir analiz yöntemidir. ÖPA'nın ilgi çekici yönlerinden biri de elde edilen sonuçların kolay ve anlaşılır grafiklere dönüştürülebilmesidir (Martilla \& James 1977, 77). Bu açıdan ÖPA, kolay anlaşılır, kullanıcı dostu, pratik bir yöntemdir (Chan \& Cheung 2005, 25). ÖPA temelde iki soruya cevap aramaktadir. Bunlar:

1. Bu özellik müşteriler açısından ne kadar önemlidir?

2. Bu özelliklere ilişkin performansımız (oluşturduğumuz memnuniyet) ne kadar yüksektir? (Martilla \& James 1977, 77). 
Yöntemin uygulanmasında ürün ve hizmetle ilgili önem ve performans skorları hesaplanmaktadır. Bu skorlar özelliğe ait x ve y koordinat değerlerini oluşturmaktadır. Elde edilen tüm sonuclar x ekseninde performansın (memnuniyet), y ekseninde önemin yer aldığ 1 bir matris üzerinde gosterilmektedir (Matzler et al. 2004, 114). Bu skorlar özelliğe ait x ve y koordinat değerlerini oluşturmaktadır. Elde edilen tüm sonuclar x ekseninde performansın, y ekseninde önemin yer aldığı bir matris üzerinde gösterilmektedir Ölçümde kullanılan özelliklerin önem ve performanslarının ortalaması ayrı ayrı hesaplanarak eksenlerinin kesişme noktası belirlenmektedir. Önem ve performans eksenlerinin kesişmesi sonucu, dört hücre elde edilmektedir:

Hücre 1: Korunması gerekenler - (Yüksek önem - yüksek performans): Müşteriler tarafından hem önemli bulunan hem de performansı başarılı değerlendirilen hizmetlerin oluş̧turduğu hücredir.

Hücre 2: Yoğunlaş1lması gerekenler-(Yüksek önem - düşük performans): Müşteriler tarafından önemli bulunan fakat ortaya konulan performansın düşük seviyede kaldığı hizmetlerin oluşturduğu hücredir.

Hücre 3: Düşük öncelikliler - (Düşük önem - düşük performans): Müşteriler tarafından düşük önem düzeyinde bulunan ve performansı da düşük algılanan hizmetlerin oluşturduğu hücredir.

Hücre 4: Olası aşırılıklar - (Düşük önem - yüksek performans): Müşteriler tarafindan düşük önem düzeyinde bulunan fakat yüksek performans sergilenen hizmetlerin oluşturduğu hücredir (Martilla \& James 1977, 78).

\section{Yöntem}

Araştırmada kullanılan örneklem Antalya ilinde faaliyet gösteren A grubu seyahat acentalarında çalışan 3000 kullanıcı arasından basit tesadüfi örnekleme yöntemi ile belirlenmiştir. Araştırma evreni içerisinden gerekli örneklem sayısının hesaplanmasında, evreni temsil edecek olan örneklem büyüklüğü \%95 güvenilirlik düzeyinde $\% 5$ yanılma payı ile 372 olarak belirlenmiştir (Nunnally 1978). Veriler 2018 yılının Mayıs-Haziran ayları arasında toplanmıştır. Araştırmada kullanılan ölçüm aracının geliştirilmesi için öncelikle 210 kullanıcıdan toplanan veriler değerlendirilmiştir. Yapılan analizler doğrultusunda toplanan ikinci grup veri seti üzerinden yap1 geçerliliği için doğrulayıcı faktör analizi ve sonrasında önem performans analizi gerçekleştirilmiştir. Bu analizler için toplanan 390 adet anketin 7 adeti kullanılamaz olduğundan toplam 383 anket formu ile analizler gerçekleştirilmiştir.

Literatür taraması ve uzman görüşleri doğrultusunda geliştirilen ölçüm aracı ile toplanan veriler önem-performans analizi yöntemi ile analiz edilmiştir. Yöntem, enformasyon sistem niteliklerine kullanıcıların verdiği önemi ve bu niteliklerin performansını ortaya koymaktadır. Çalışmanın amacı gereği seyahat acentalarında kullanılan enformasyon sistemlerinin başarısının değerlendirilmesinde her bir niteliğin önem derecesi ve performans1 ile ilgili ortalamalar hesaplanmıştır. Bu şekilde enformasyon sistemi ile ilgili ÖPA matrisinde yer alan özellikler kapsamında hangi özelliklerinin korunması gerektiği, hangi özelliklerin iyileştirilmesi veya hangilerinin desteklenmesi gerektiği ile ilgili çıkarımlar yapılmıştır.

Araştırma kapsamında veri toplama aracı olarak kullanılan anket iki bölümden oluşmaktadır. İlk bölümde, ankete katılan katılımcılara yönelik demografik sorular, ikinci bölümde ise enformasyon sistem başarısını ölçmeye yönelik ifadeler yer almaktadır. Kullanılan ölçekte, 5 maddeli likert tipi ölçek kullanılmıştır. Önem-Performans Analizi olmasından ötürü tüm değişkenlere ait soru cevapları Önem değerlendirmesi için 1= Hiç Önemli Değil, 2= Önemli Değil, 3 $=$ Kararsızım , $4=$ Önemli ve $5=$ Çok Önemli şeklinde kullanılmıştır. Performans değerlendirmesi için ise aynı ölçek 1 = "Kötü" , 2 = "Orta" , 3 = "İyi" , 4 = "Çok İyi" , 5 = "Mükemmel" cevapları 
ile sunulmuştur. Bu şekilde sunduğumuz enformasyon sistemi kullanıcıları her bir boyut da yer alan ifadelerin kendileri için önemlilik derecesini ve ardından niteliklere ilişkin kullanılan sistem için performans değerlemesi yapabilmişlerdir. Araştırmanın amacı gereği ortalamalar üzerinden analizler gerçekleştirileceği için öncelikle verilerin normal dağılıma uygun olup olmadığı test edilmiştir. Ölçüm aracı geliştirme süreci ilgili bölümde detaylı olarak verilmiştir.

\section{Veri Toplama Aracı}

Enformasyon sistemlerinin başarısını ölçmek için araştırma bağlamına uygun olarak bir ölçüm aracı geliştirilmiştir. Ölçek geliştirme süreci genel olarak soru havuzunun oluşturulması, ölçeğin yapılandırılması ve ölçeğin değerlendirilmesi olmak üzere üç aşamadan oluşmaktadır. Ölçüm aracı geliştirme sürecinde hem nitel hem de nicel araştırma tekniklerinden faydalanılmıştır. Ölçüm aracı geliştirme süreci için Churchill \& Gilbert 1979 tarafından önerilen model kullanılmıştır. İlk olarak soru havuzu oluşturulmuştur. Havuzdaki maddeler pek çok kaynaktan sağlanabilmektedir. Bu kaynaklar önceden yapılmış ölçek geliştirme makaleleri, yanıtlayıcıları temsil edebilecek örnek bireyler, konuyla alakalı uzman kişilerin ifadeleri, araştırmacının teorik yapı ile ilgili kendi bilgi ve ifadeleri olarak suralanabilir.

Ölçek geliştirme sürecinin ilk aşamasında ölçekte yer alabilecek soruların tespiti doğrultusunda tümdengelim ve tümevarım yöntemleri izlenebilmektedir. Geliştirilecek olan ölçek ile ilgili yeterli kuramsal çalışmanın bulunması sebebiyle tümdengelim yöntemi kullanılarak literatür taraması yapılmış ve konu ile ilgili kavramsal çerçeve netleştirilmeye çalışılmıştır. Bu sayede ölçek kuramsal bir temele oturtulabildiği için ölçeğin içerik geçerliliği artmaktadır. Yapılan literatür taramasında enformasyon sistem başarısını ölçmek için yapılmış çalışmalar incelenmiştir. Buna paralel olarak seyahat işletmelerinde çalışan deneyimli enformasyon sistemi kullanıcıları (12 kişi) ile mülakatlar yapılmıştır. Daha sonra oluşturulan ölçek ve maddeler kapsam geçerliliğinin sağlanabilmesi için alanında uzman akademisyenler tarafindan incelenmiştir. Yapılan incelemelerde ölçme aracının hedeflenen konu kapsamını temsil edebilir olduğu görüşüne varılmıştır.

Ölçekte yer alabilecek ifadelerin derlenmesinin ardından ölçekteki ifadeler seyahat acentalarında çeşitli departmanlarda çalışan enformasyon sistemi kullanıcılarına uygulanarak ifadelerin anlaşılabilirliği bir kez daha sınanmıştır. Soru formunda yer alan ifadelerin kısa, anlaşılır ve az ve yeterli sayıda olmasına özen gösterilmiştir. Ölçekte toplam 3 boyut ve 21 ifade yer almaktadır. Soru formuna araştırmanın amacına uygun olarak demografik değişkenlerin eklenmesi ile soru formu veri toplamaya hazır hale gelmiştir.

Kullanıcıların seyahat acentası enformasyon sistem performansını ölçmek için hazırlanan ifadelere yönelik tutumların ölçümünde 5'li Likert tipi ölçek kullanılmıştır. Likert tipi ölçekler sosyal bilimlerde tutum ölçekleri içinde en yaygın olarak kullanılandır. Daha sonra bu anket taslağının asıl örnekleme benzer bir örneklemde pilot çalışması yapılmıştır. Öncelikle ölçeğin güvenilirliğini test etmek için seyahat acentası enformasyon sistem performans1 ölçümüne yönelik ifadeler iç tutarlılık açısından incelenmiştir. Bunun için hesaplanan Cronbach alfa değeri 0,96 olarak bulunmuştur $(n=210)$. Bu değer genel kabul gören kriter değeri olan 0,70 'den büyüktür ve iyi bir değer olarak kabul edilir (Nunnally 1978; Hair et al. 1998).

Bir ölçme aracında bulunmasını istediğimiz temel yapısal niteliklerden biri de geçerliliktir. Geçerlilik testi için ilk etapta toplanan 210 anket üzerinden öncelikle açıklayıcı faktör analizi yapılmıştır. Ölçeğin yapılandırılması aşamasında belirlenen 21 ifade açıklayıcı faktör analizi aracılığıyla analiz edilmiş ve ölçeğin temel faktörleri belirlenmeye çalışılmıştır. Araştırma grubunun faktör analizine uygunluğunu ortaya koymak üzere Kaiser-Mayer-Olkin (KMO) değeri hesaplanmıştır. Bu değer örneklem büyüklüğü ve maddeler arasındaki korelasyonun faktör analizine uygunluğunu ortaya koyan bu değer için 0,60 ve üzeri yeterli kabul edilmektedir 
(Büyüköztürk 2002). Çalışmada araştırma grubuna ilişkin KMO değeri ,945 olarak belirlenmiştir. Dağılımın normallik düzeyinin faktör analizinin koşularını karşılama durumu Barlett Testi ile incelenmiş ve 5244,619 olarak hesaplanmıştır. Faktör sayısına kısıtlama getirilmeden yapılan temel bileşenler faktör analizinde varimax döndürme yöntemi kullanılmıştır. Faktör yapısını bozan ve birden fazla faktörde yer alan ifadeler ölçekten çıkarılmıştır. Yapılan bir dizi faktör analizi sonucunda 5 ifade ölçekten çıkarılmıştır. Ulaşılan son 16 sorudan oluşan üç faktörlü bir yapıya ulaşılmıştır. Bu yeni ölçeğin Cronbach alfa değeri 0,95 olarak bulunmuştur. Faktör analizi sonucu elde edilen 3 faktörün toplam varyansı açılama oranı da 74.93 dür (Tablo 1).

Tablo 1. Açıklayıcı Faktör Analizi Sonuçları

\begin{tabular}{|c|c|c|c|c|}
\hline $\begin{array}{l}\text { İfade } \\
\text { No }\end{array}$ & İfadeler & $\alpha$ & $\begin{array}{l}\text { Açıklanan } \\
\text { Varyans }\end{array}$ & $\begin{array}{l}\text { Faktör } \\
\text { Yükleri }\end{array}$ \\
\hline $\begin{array}{l}\text { HK3 } \\
\text { HK1 } \\
\text { HK2 } \\
\text { HK5 } \\
\text { HK4 } \\
\text { SK10 } \\
\text { SK12 } \\
\text { SK11 } \\
\text { SK9 } \\
\text { SK7 } \\
\text { SK3 } \\
\text { SK2 } \\
\text { EK1 } \\
\text { EK2 } \\
\text { EK3 } \\
\text { EK4 }\end{array}$ & $\begin{array}{l}\text { Faktör 1. Destek Sağlayan Teknoloji Şirketinin Hizmet Kalitesi } \\
\text { Sistem ile ilgili hızlı destek alabiliyor olmak } \\
\text { Sistem ile ilgili ihtiyaç duyulan anda teknik destek alabiliyor olmak } \\
\text { Sistem ile ilgili yeterli destek alabiliyor olmak } \\
\text { Sistem ile ilgili yetkin ve tecrübeli insanlardan destek alabiliyor olmak } \\
\text { Sistem ile ilgili yeterli eğitim alabiliyor olmak } \\
\text { Faktör 2. Sistem Kalitesi } \\
\text { Sistemin işletmedeki farklı bölümlerden gelen bilgiyi bütünleştirmesi } \\
\text { Sistemin diğer yazılımlar ile entegrasyon kabiliyetinin olması } \\
\text { Sistem kullanımının karar alma becerisini arttırması } \\
\text { Sistemin işteki verimliliği artırması } \\
\text { Sistemin yeni talep ve koşullara uyarlanabilecek esnekliğe sahip olması } \\
\text { Sistemin işim için ihtiyaç duyulan özellik ve fonksiyonlara sahip olmas1 } \\
\text { Sistemin hızlı olması } \\
\text { Faktör 3. Enformasyon Kalitesi } \\
\text { Sistemin doğru bilgi üretmesi } \\
\text { Sistemden alınan bilginin açık ve anlaşılır olması } \\
\text { Sistemin ürettiği raporların güvenilir olması } \\
\text { Sistemin sağladığı bilginin iyi düzenlenmiş olması }\end{array}$ & $\begin{array}{l}0,94 \\
0,91\end{array}$ & $\begin{array}{l}59,13 \\
10,11\end{array}$ & $\begin{array}{l}0,865 \\
0,851 \\
0,850 \\
0,818 \\
0,727 \\
\\
0,800 \\
0,785 \\
0,779 \\
0,663 \\
0,654 \\
0,592 \\
0,562 \\
\\
0,811 \\
0,784 \\
0,765 \\
0,748\end{array}$ \\
\hline & $\begin{array}{ll}\text { KMO } & 0,95 \mathrm{ve} \\
\text { Bartlett } & 5244,619 \\
\text { Toplam Açılanan Varyans } 74,93\end{array}$ & \multicolumn{3}{|c|}{ Genel Cronbach Alpha 0,95 } \\
\hline
\end{tabular}

Faktörlerden ilki incelendiğinde kullanıcılara destek sağlayan teknoloji firmasının hizmet kalitesini tanımlayan sorulardan oluştuğu görülmektedir. Bu ilk boyut toplam varyansın \%59,13 'ünü açıklamaktadır. İkinci faktör sistemin sağladığı hizmet kalitesi $(\% 10,1)$, üçüncü faktör ise sistemin sağladığı enformasyon kalitesi $(\% 5,68)$ ile ilgilidir.

Ölçüm aracının yapı geçerliliğini test etmek için toplanan 383 adet anket üzerinden doğrulayıcı faktör analizi yapılmıştır. Açıklayıcı faktör analizinden sonra elde edilen 3 boyut ve 16 maddeden oluşan ölçek doğrulayıcı faktör analizi ile test edilmiştir. Bu amaçla öncelikle modelin tanımlanması gerekmektedir. Modelin tanımlanması, yapılan analizin kuramsal yapıya dayandırılmasıdır. $\mathrm{Bu}$ aşamada modelin tanımlanmasında ilgili literatürdeki kavramsal gerekçeden ve bu çerçeve temel alınarak gerçekleştirilen açıklayıcı faktör analizi sonuçlarından yararlanılmıştır. Bu sonuçlara uygun olarak açıklayıcı faktör analizi aşamasında belirlenen faktör yapıları path diyagramlarından yararlanılarak ölçme modeli biçiminde tasarlanmıştır. Ölçme modeline ait standardize edilmiş parametre değerleri, $t$ değerleri Tablo 2'de verilmiştir. Tabloda modele ait parametre tahminleri yer almaktadır ve şekildeki faktör ağırlıkları maksimum olabilirlik metoduna göre standardize edilmiş katsayı tahminleri olarak hesaplanmıştır. Bütün 
katsayılar 0,01 önem derecesinde anlamlı bulunmuştur. Modele ait uyum indeksleri Tablo 2' de toplu olarak gösterilmektedir. Bu bulgular ifadelerin faktörler tarafından doğru açıklandığını göstermektedir. Bu durum ölçeklerin yapı geçerliliğinin bir kanıtı olarak kabul edilebilir.

Tablo 2. Doğrulayıcı Faktör Analizi Sonuçları

\begin{tabular}{|c|c|c|c|}
\hline \multicolumn{2}{|c|}{ Ölçek Maddeleri } & $\begin{array}{l}\text { Standardize } \\
\text { Parametre } \\
\text { Değerleri }\end{array}$ & $\begin{array}{l}\text { T- } \\
\text { değerleri }\end{array}$ \\
\hline \multicolumn{2}{|c|}{ Hizmet Kalitesi $(\mathrm{AVE}=, 0,68 ; \mathrm{CR}=, 91)$} & & \multirow{6}{*}{$\begin{array}{l}22,20 \\
22,89 \\
23,63 \\
20,00 \\
18,09\end{array}$} \\
\hline (HK3) & Sistem ile ilgili hızlı destek alabiliyor olmak & 0,89 & \\
\hline (HK1) & Sistem ile ilgili ihtiyaç duyulan anda teknik destek alabiliyor olmak & 0,91 & \\
\hline$(\mathrm{HK} 2)$ & Sistem ile ilgili yeterli destek alabiliyor olmak & 0,93 & \\
\hline (HK5) & Sistem ile ilgili yetkin ve tecrübeli insanlardan destek alabiliyor olmak & 0,84 & \\
\hline (HK4) & Sistem ile ilgili yeterli eğitim alabiliyor olmak & 0,78 & \\
\hline \multicolumn{2}{|c|}{ Sistem Kalitesi $(\mathrm{AVE}=, 49 ; \mathrm{CR}=0,87)$} & & \multirow{8}{*}{$\begin{array}{l}19,01 \\
16,73 \\
20,69 \\
18,84 \\
17,44 \\
17,40 \\
16,14\end{array}$} \\
\hline (SK10) & Sistemin işletmedeki farklı bölümlerden gelen bilgiyi bütünleştirmesi & 0,81 & \\
\hline (SK12) & Sistemin diğer yazılımlar ile entegrasyon kabiliyetinin olması & 0,75 & \\
\hline (SK11) & Sistem kullanımının karar alma becerisini arttırması & 0,86 & \\
\hline (SK9) & Sistemin işteki verimliliği artırması & 0,81 & \\
\hline (SK7) & Sistemin yeni talep ve koşullara uyarlanabilecek esnekliğe sahip olması & 0,77 & \\
\hline (SK3) & Sistemin işim için ihtiyaç duyulan özellik ve fonksiyonlara sahip olması & 0,77 & \\
\hline (SK2) & Sistemin hizlı olmas & 0,73 & \\
\hline \multicolumn{2}{|c|}{ Enformasyon Kalitesi $(\mathrm{AVE}=, \mathbf{6 0} ; \mathrm{CR}=, 86)$} & & \multirow{5}{*}{$\begin{array}{l}21,24 \\
20,61 \\
20,44 \\
19,90\end{array}$} \\
\hline$(\mathrm{EK} 1)$ & Sistemin doğru bilgi üretmesi & 0,87 & \\
\hline$(\mathrm{EK} 2)$ & Sistemden alınan bilginin açık ve anlaşılır olması & 0,86 & \\
\hline (EK3) & Sistemin ürettiği raporların güvenilir olması & 0,85 & \\
\hline (EK4) & Sistemin sağladığı bilginin iyi düzenlenmiş olması & 0,84 & \\
\hline \multicolumn{4}{|c|}{$\begin{array}{l}\text { Ölçme Modelinin Uyum İndeksleri } \chi 2=354,99 \mathrm{df}=101, \mathrm{CFI}=0,98, \mathrm{RMSEA}=0.081, \mathrm{PNFI}=0,82 \mathrm{SRMR}=0,042 \text {, } \\
\text { GFI }=0,90\end{array}$} \\
\hline \multicolumn{4}{|c|}{$\begin{array}{l}\text { Not: Bütün standardize edilmiş parametre değerleri } 0.01 \text { düzeyinde anlamlıdır. } \\
\text { AVE = Ortalama açıllanan varyans; CR = Composite reliability, PNFI = Parsimony normed fit index; } \\
\text { CFI=comparative fit index; RMSEA = Root mean square error of approximation; SRMR = Standardized root } \\
\text { mean square residual. GFI=Goodness of fit Index }\end{array}$} \\
\hline
\end{tabular}

Yakınsama geçerliliği için Fornell \& Larcker'a (1981) göre madde güvenirliği, yap1 güvenirliği ve açıklanan ortalama varyans hesaplanmıştır. Her bir boyut için hesaplanan birleşik güvenirlik (composite reliability) Tablo 2'de gösterilmektedir. Tüm değerler kabul edilebilir sinır olan 0.70'in üzerindedir (Fornell \& Larcker 1981;Hair et al. 1998; Nunally 1978). Yakınsama geçerliliğinin göstergelerinden biri de ortalama açıklanan varyans (AVE) oranıdır. Bu değerin 0.50 'ye eşit veya bu değerden yüksek olması beklenendir (Bagozzi et al. 1991). Sistem kalitesi $(0,49)$ hariç tüm AVE değerleri 0,50'nin üzerindedir. Ölçekte yer alan boyutlar (faktörler) arasında korelasyon değerleri Tablo 3'de gösterilmektedir ve tüm boyutlar 0.01 düzeyinde anlamlıdır. Korelasyon değerleri gerekli kriterleri sağladığı için ölçeğin yakınsama geçerliliğinin varlığından söz edilebilir. Ayrışma geçerliliği, ölçeğin boyutları arasındaki ayrışma derecesini göstermektedir. Ayrışma geçerliliği için Fornell \& Larcker (1981)'in önerdiği yöntem kullanılmıştır. Buna göre, bir boyuta ait ortalama açıklanan varyansın o boyutun diğer boyutlarla arasındaki korelasyon katsayısının karesinden büyük olması (Ortalama açıklanan 
varyans $>$ Kor. $^{2}$ ) gerektiğini ortaya koymaktadır (Fornell \& Larcker 1981, 46). AVE değerleri ile korelasyon değerleri incelendiğinde tüm değerler ölçekler için ayrışma geçerliliğinin mevcut olduğunu göstermektedir.

Tablo 3. Faktörler Arası Korelasyon ve AOV Değerleri

\begin{tabular}{|c|c|c|c|}
\hline \multicolumn{4}{|c|}{$\left(\right.$ Korelasyonlar) ${ }^{2}$} \\
\hline & $\mathrm{AOV}$ & HK 1 & SK 2 \\
\hline HK 1 & 0,68 & & \\
\hline SK 2 & 0,49 & $0,65(* *)$ & \\
\hline EK 3 & 0,60 & $0,62(* *)$ & $0,77(* *)$ \\
\hline
\end{tabular}

** 0.01 düzeyinde anlaml 1

\section{Bulgular}

Çalışmanın bu bölümünde katılımcıların demografik özelliklerine ilişkin bulgulara yer verilmiştir. Çalıştıkları departman bilgisine göre kullanıcıların dağılımına baktığımızda katılımc1ların \%27,9 u muhasebe, \% 14,9'u operasyon, \% 42,6's1 rezervasyon-operasyon departman1 çalışanları, \%14,6's1 yönetim grubu olarak görülmektedir. Katılımcıların \%55,6 ile kadın kullanıcılardan oluşmaktadır. Katılımcıların eğitim durumlarına bakıldığında ise 72,1 gibi yüksek bir oran ile üniversite mezunu olduğu görülmektedir. Verilen cevaplara göre katılımcilarımızdan 92 kişinin (\% 24) okudukları okul müfredatlarında seyahat acentası programı eğitimi almış oldukları tespit edilmiştir.

Araştırmamız kapsamında anketi uyguladığımız 383 adet enformasyon sistemi kullanıcısının ölçeklere verdikleri önem değerlerini analiz ettiğimizde kullanıcıların ölçüm aracımızda 16 ölçeğin tamamına 4 üzerinde önem değeri verdikleri görülmektedir. Ölçekte yer alan ifadelerin beşli Likert düzeninde hazırlandığı dikkate alındığında alındığında verilen cevap ortalamalarının 4-5 aralığına gelmesi tüm kriterlerin kullanıcılar için önemli olduğunu göstermektedir. Tüm ifadeler arasında en önemli olan ifadeler 4,70 üzerinde kalan EK3-Sistemin ürettiği raporların güvenilir olması (4,75 ortalama), EK2-Sistemden alınan bilginin açık ve anlaş1lır olmas1 (4,73 ortalama), EK1-Sistemin doğru bilgi üretmesi (4,71 ortalama) ve SK3-Sistemin işim için ihtiyaç duyulan özellik ve fonksiyonlara sahip olması (4,70 ortalama) ifadeleri olduğu görülmektedir. SK11-Sistemin kullanımının karar alma becerisini arttırması ifadesi ise verilen ortalama 4,37 önem derecesi ile listenin en altında kalmaktadır. (bkz. Tablo 4).

Performansa yönelik olarak gelen değerlendirme sonuçlarını analiz ettiğimizde kullanıc1ların performans değerlemelerinin 2,99 - 3,38 puan aralığında kaldığı görülmektedir. En yüksek performans değeri alan ifadeler burada EK1-Sistemin doğru bilgi üretmesi, EK2-Sistemden alınan bilginin açık ve anlaşılır olması, EK3-Sistemin ürettiği raporların güvenilir olması olarak görülmektedir. SK7-Sistemin yeni talep ve koşullara uyarlanabilecek esnekliğe sahip olmas1 ifadesi 2,99 puanı ile en düşük performans ortalamasını alarak liste sonunda görülmektedir. Daha sonra önem ve performans ortalamalarının farklarını da alarak daha net bir değerlendirme yapılmıştır. Tablo 4'de görüldüğü gibi sistem kalitesi ve hizmet kalitesi ölçeklerimizde kullanıcıların önem verdiği 5 ifadenin; SK2-Sistemin hızlı olması, SK3-Sistemin işim için ihtiyaç duyulan özellik ve fonksiyonlara sahip olmas1, HK3-Sistem ile ilgili hizlı destek alabiliyor olmak, HK4-Sistem ile ilgili yeterli eğitim alabiliyor olmak, SK7-Sistemin yeni talep ve koşullara uyarlanabilecek esnekliğe sahip olması ifadelerinin performans değerlerinin malesef düşük olduğu görülmektedir. $\mathrm{Bu}$ anlamda bu konular için kullanılan enformasyon sistemlerinin performansları kullanıcı beklentileri ile örtüşmemektedir. 
Tablo 4. Önem-Performans ortalamaları ve Farkları

\begin{tabular}{lllll}
$\begin{array}{l}\text { Iffade } \\
\text { No }\end{array}$ & İfadeler & Önem & Perf. & Fark (P-Ö) \\
\hline EK1 & Sistemin doğru bilgi üretmesi & 4,71 & 3,38 & $-1,33$ \\
\hline EK2 & Sistemden alınan bilginin açık ve anlaşılır olması & 4,73 & 3,34 & $-1,39$ \\
\hline EK3 & Sistemin ürettiği raporların güvenilir olması & 4,75 & 3,34 & $-1,41$ \\
\hline EK4 & Sistemin sağladığı bilginin iyi düzenlenmiş olması & 4,62 & 3,30 & $-1,32$ \\
\hline SK2 & Sistemin hızlı olması & 4,68 & 3,07 & $-1,61$ \\
\hline SK3 & Sistemin işim için ihtiyaç duyulan özellik ve fonksiyonlara sahip olmas1 & 4,70 & 3,21 & $-1,50$ \\
\hline SK7 & Sistemin yeni talep ve koşullara uyarlanabilecek esnekliğe sahip olmas1 & 4,55 & 2,99 & $-1,55$ \\
\hline SK9 & Sistemin işteki verimliliği artırması & 4,60 & 3,23 & $-1,36$ \\
\hline SK10 & Sistemin işletmedeki farklı bölümlerden gelen bilgiyi bütünleştirmesi & 4,57 & 3,14 & $-1,43$ \\
\hline SK11 & Sistem kullanımının karar alma becerisini artırması & 4,37 & 3,09 & $-1,29$ \\
\hline SK12 & Sistemin diğer yazılımlar ile entegrasyon kabiliyetinin olması & 4,51 & 3,03 & $-1,48$ \\
\hline HK1 & Sistem ile ilgili ihtiyaç duyulan anda teknik destek alabiliyor olmak & 4,68 & 3,25 & $-1,43$ \\
\hline HK2 & Sistem ile ilgili yeterli destek alabiliyor olmak & 4,68 & 3,19 & $-1,49$ \\
\hline HK3 & Sistem ile ilgili hızlı destek alabiliyor olmak & 4,68 & 3,13 & $-1,55$ \\
\hline HK4 & Sistem ile ilgili yeterli eğitim alabiliyor olmak & 4,61 & 3,11 & $-1,50$ \\
\hline HK5 & Sistem ile ilgili yetkin ve tecrübeli insanlardan destek alabiliyor olmak & 4,66 & 3,26 & $-1,40$ \\
\hline & & & \\
\hline
\end{tabular}

Ölçüm aracındaki niteliklerin ortalamaları ile SPSS sistemi üzerinde ÖPA matrisi oluşturulmuştur. Önem-performans matrisi incelendiğinde sistem kullanıcılarının sistem niteliklerine verdikleri değer ortalamalarını 4 grup olarak $\mathrm{X}$ ve $\mathrm{Y}$ düzleminde yerleştirmiş olarak izleriz. Ortaya çıkan matris Şekil 1'de görülmektedir.

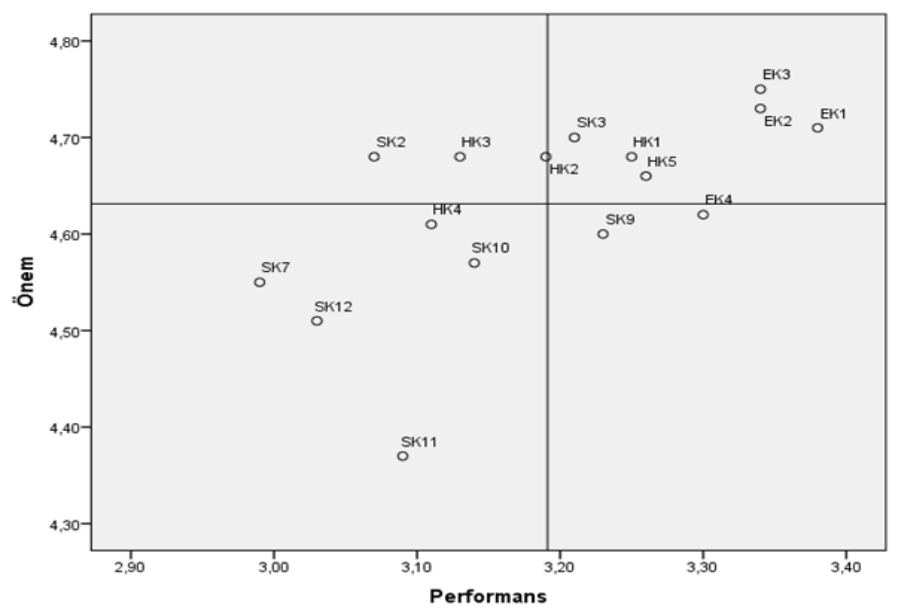

Şek. 1. Enformasyon Sistem Özellikleri Önem-Performans Matrisi 
Dörtlü Hücre 1: Oluşan matrisin bu bölümünde anketimizde yer alan 6 ifade bulunmaktadır. Enformasyon kalitesi ölçeğimizde yüksek önem derecesi alan EK1-Sistemin doğru bilgi üretmesi, EK2-Sistemden alınan bilginin açık ve anlaş1lır olmas1 ve EK3-Sistemin ürettiği raporların güvenilir olması şeklinde yer alan ifadelerimiz, kullanıcılardan performans olarak da yüksek puanlar almıştır. Hizmet Kalitesi ölçeğimizden HK1-Sistem ile ilgili ihtiyaç duyulan anda teknik destek alabiliyor olmak, HK5-Sistem ile ilgili yetkin ve tecrübeli insanlardan destek alabiliyor olmak, SK3-Sistemin işim için ihtiyaç duyulan özellik ve fonksiyonlara sahip olması konularında da yüksek önem derecesi ve yüksek performans ortalaması çıkmıştır. Dolayısı ile önem-performans analizine göre yorumladığımızda belli bir memnuniyet düzeyi yakalanmış olduğu için tüm bu ifadelerde yer alan konulara özen gösterilmesi ve memnuniyeti seviyesini korumak için dikkatle hizmet verilmesi önerilebilir.

Dörtlü Hücre 2: Matriste 2. bölümde anketimizdeki sistem kalitesi ölçeğinden SK2-Sistemin hızlı olması, hizmet kalitesi ölçeğinden HK2-Sistem ile ilgili yeterli destek alabiliyor olmak ve HK3-Sistem ile ilgili hızlı destek alabiliyor olmak ifadelerinde yüksek önem derecelerine ulaşılmıştır ancak kullandıkları enformasyon sistemlerinden performans olarak bekledikleri ölçüde sonuç alamadıkları görülmektedir. Önem-performans analizine göre, tüm bu belirtilen konularda performansın geliştirilmesi gerekmektedir. Sistem kullanıcıları için hizmetler tatmin edici düzeyde değildir ve hizmet çabalarının arttırılması, kullanıcıların beklentilerine dikkat edilmesi gerekmektedir.

Dörtlü Hücre 3: Matrisin bu bölümünde anketteki sistem kalitesi ölçeğimizden SK7Sistemin yeni talep ve koşullara uyarlanabilecek esnekliğe sahip olması, SK10-Sistemin işletmedeki farklı bölümlerden gelen bilgiyi bütünleştirmesi, SK11-Sistem kullanımının karar alma becerisini artırması, SK12-Sistemin diğer yazılımlar ile entegrasyon kabiliyetinin olması ve Hizmet kalitesi ölçeğinden HK4-Sistem ile ilgili yeterli eğitim alabiliyor olmak ifadeleri yer almıştır. Katılımcılar için bu özellikler önemli olmamakla beraber değerlemesi yapılan programlarda performanslarında iyi olmadığını belirtmektedirler. Bu konuların geliştirilmesi için yüksek bir yoğunlaşmaya gerek bulunmamaktadır. Ancak kısıtlı bir kaynak ile bu özelliklerin üzerine gidilmesi yeterli görülmektedir.

Dörtlü Hücre 4: Oluşan Matrisin bu bölümünde enformasyon kalitesi ölçeğinden EK4Sistemin sağladığı bilginin iyi düzenlenmiş olması ifadesi, sistem kalitesi ölçeğinden SK9Sistemin işteki verimliliği artırması ifadesi yer almaktadır. Bu hücrede yer alan konularımıza sistem kullanıcılarının düşük önem atfettiğini görüyoruz, bu nedenle bu alanda göstermiş olunan yüksek performans değerleri Kullanıcıların tatmin düzeylerini arttırması beklenmez. Çünkü kullanıcıların önem verdiği başka konularda mevcuttur, asıl konsantre olunması gereken Hücre 2 'de yer alan konulardır. Matris kaynakların 4. Hücrede yer alan konulara ayrılmasından ziyade 2. Hücreye yoğunlaşılmasını söylemektedir bize. Gereksiz yere bu konularda kaynak ayrılmaması önerilmektedir.

Ölçekte bulunan her bir hücrede yer alan ifadelerini ve detaylarını aşağıda listelenen tabloda verilecektir (bkz. Tablo 5).

Tablo 5. Önem-Performans Matrise Göre 4 Bölüm Gruplu Liste

\begin{tabular}{|l|l|l|}
\hline 1-Korunmas1 & EK1 & Sistemin doğru bilgi üretmesi \\
gerekenler & EK2 & Sistemden alınan bilginin açık ve anlaş1lır olmas1 \\
& EK3 & Sistemin ürettiği raporların güvenilir olmas1 \\
& SK3 & Sistemin işim için ihtiyaç duyulan özellik ve fonksiyonlara sahip olmas1 \\
& HK1 & Sistem ile ilgili ihtiyaç duyulan anda teknik destek alabiliyor olmak \\
& HK5 & Sistem ile ilgili yetkin ve tecrübeli insanlardan destek alabiliyor olmak \\
\hline
\end{tabular}




\begin{tabular}{|c|c|c|}
\hline $\begin{array}{l}\text { 2-Yoğunlaşı1ması } \\
\text { gerekenler }\end{array}$ & $\begin{array}{l}\text { SK2 } \\
\text { HK2 } \\
\text { HK3 }\end{array}$ & $\begin{array}{l}\text { Sistemin hılı olması } \\
\text { Sistem ile ilgili yeterli destek alabiliyor olmak } \\
\text { Sistem ile ilgili hızlı destek alabiliyor olmak }\end{array}$ \\
\hline 3-Düşük öncelikler & $\begin{array}{l}\text { SK7 } \\
\text { SK10 } \\
\text { SK11 } \\
\text { SK12 } \\
\text { HK4 }\end{array}$ & $\begin{array}{l}\text { Sistemin yeni talep ve koşullara uyarlanabilecek esnekliğe sahip olması } \\
\text { Sistemin işletmedeki farklı bölümlerden gelen bilgiyi bütünleştirmesi } \\
\text { Sistem kullanımının karar alma becerisini artırması } \\
\text { Sistemin diğer yazılımlar ile entegrasyon kabiliyetinin olması } \\
\text { Sistem ile ilgili yeterli eğitim alabiliyor olmak }\end{array}$ \\
\hline 4-Olası aşırılıklar & $\begin{array}{l}\text { EK4 } \\
\text { SK9 }\end{array}$ & $\begin{array}{l}\text { Sistemin sağladığı bilginin iyi düzenlenmiş olması } \\
\text { Sistemin işteki verimliliği artırması }\end{array}$ \\
\hline
\end{tabular}

\section{Sonuç, Tartışma ve Öneriler}

Seyahat acentaları enformasyon sistem kullanıcılarının sistem niteliklerine verdikleri önem ve bu niteliklerin performansının önem-performans analizi ile incelendiği bu çalışmada sistemin enformasyon kalitesi, sistem kalitesi ve hizmet kalitesi unsurları tek tek değerlendirilmiştir. Uygulanan açıklayıcı faktör analizinde, kullanıcılara destek sağlayan teknoloji firmasının hizmet kalitesinin sistem performasında etkili olan en önemli faktör olduğu tespit edilmiştir. Katılımcıların bu boyut altında yer alan enformasyon sistemleri için aldıkları eğitim ve teknik destek hizmetleri ile ilgili ifadelere yönelik tutum ortalamaları oldukça yüksektir. Bunun temel nedeni seyahat acentalarının yüksek tempoda ve yoğun stres altında çalışma durumunda kalmaları ve ihtiyaç duydukları anda teknik destek alma ihtiyacı duymalarından kaynaklanmaktadir.

Araştırma katılımcıları karşılayıcı seyahat acentası çalışanlarından oluşmaktadır. Türkiye'de turist gelişleri açısından yoğunluğu seyahat aktivitesi gerçekleşen turizm bölgesine göre değişmekle birlikte ağırlıklı olarak 1 Nisan-31 Ekim tarihleri arasındadır. Turistlere karşılama hizmeti sağlayan tüm seyahat acentaları bütün yaz sezonu boyunca tempolu ve sürekli bir şekilde rezervasyon hizmetleri, geliş ve dönüş transfer hizmetleri vermek, tur organizasyonları yapmak, doluluk takibatları yaparak kendi müşterilerinin sorunsuz bir şekilde rezervasyonu olan otellerde konaklamaları için düzenli ve aralıksız bir operasyon yönetmek zorundadır. Sezonda gelişebilecek olan her türlü aksaklık veya krizlere karşı da esnek olabilmeli ve hızlı aksiyon alma kabiliyetinde olmalıdırlar. Otel ile acenta arasındaki otel-oda doluluğu ve en iyi fiyat ilişkisinden kaynaklı çok yoğun, zaman zaman çekişmeli ve taraflardan birisinin avantajına olmak üzere ticari alışveriş vardır. Süregelen bu görüşmeler her zaman anlaşma ile sonuçlanmayıp bazen sorunlar çıkabilmektedir. Bu kriz zamanlarında oluşan durumlara uygun çözümler geliştirilmesi ve hizmetlerin aksamaması gerekmektedir. Seyahat acentaları yukarıda sözü edilen yüksek tempolu operasyonu yaparken bir yandan da operasyonu yapılan sezonun şartlarını değerlendirerek bir sonraki kış sezonu ve devamında bir sonraki yılın yaz sezonuna ait otel kontrat hazırlıklarını tamamlama gayreti içindedirler.

$\mathrm{Bu}$ şekilde hassas, incelikli, hizmette süreklilik arz eden bir turizm operasyonunu yöneten acenta çalışanlarının bu operasyonda kullandıkları operasyon destek sistemleri tüm operasyonun merkezindedir ve her bir departmanın fonksiyonlarına göre mevcut işlemleri sistem içerisinde yürütmeleri, bu sistemdeki verileri güncel tutmaları gerekmektedir. Bu nedenle kullandıkları operasyon destek sistemlerinin kesintisiz hizmet vermesi büyük önem taşımaktadır.

Seyahat acentaları güncel turizm sezonunda çok aktif, ani değişebilen, ve anlık krizlere açık hassas bir operasyon yürütmektedir ve aynı zamanda turistik hizmetleri talep eden taraf olarak tur operatörlerinin de yoğun baskısı altındadırlar. Acenta operasyonun belkemiği olan operasyon destek sisteminde (ODS) olabilecek bir aksaklık, sistemin donması, operasyonel veya 
muhasebesel raporlama yapılamaması, sistemin B2B satış kanallarına cevap vermiyor oluşu gibi konular büyük krizlere sebep olabilirler. Bir sorun meydana geldiği anda çok hızlı müdahale gerekir, burada çözüm için ilk destek alınacak yer kullanılan ODS'nin yazılım-destek hizmetini sağlayan firmadır. Bu firmalar müşteri istek /sorun geri dönüşlerini takip etmek ve kaliteli servis verebilmek için müşteri destek hattı -call center- ve/veya online kayıt takip sistemi (ticketing) kullanıyor olabilir. Acenta çalışanlarının çıkan konularını telefonla veya e-mail ile otomatik iş kaydı açarak bu firmaya ulaştırıp, hızlı çözüm almaları gerekir. Destek hizmeti veren firma ne kadar hızlı, bilgilendirmesi eğitici, açık anlaşılır, verilen bilgiler faydalı ise, çözüm için alternatif üretebiliyorsa veya sistemde çözümü yok ise bu konuda ilave geliştirme yaparak yeni özellikler ekleyerek acenta müşterisine çözüm olabiliyor ise aynı oranda kullanıcı memnuniyet seviyesini arttırabilirler.Hizmet kalitesi ölçeğimizde yer alan HK1-Sistem ile ilgili ihtiyaç duyulan anda teknik destek alabiliyor olmak ve HK5-Sistem ile ilgili yetkin ve tecrübeli insanlardan destek alabiliyor olmak ifadeleri analizlerimizde yüksek önem ortalaması almıştır. İhtiyaç duyulan bir anda bekletmeden konuyu tecrübeli yetkin destek uzmanları ile ele alıp yönetebilen bilişim firmalarının bu hizmetleri kullanıcılarda memnuniyet düzeyini de yükseltecektir.

Seyahat acentaları turizm sezonu içerisinde çeşitlilik arz eden operasyonlarını başarılı sürdürebilmek için operasyon sistemlerinden maksimum fayda sağlamak ve tüm işlemlerini bu otomasyonlar ile hızlı, verimli, doğru, güvenilir bir şekilde yapmak zorundadırlar. SK3-Sistemin ihtiyaç duyulan özellik ve fonksiyonlara sahip olması kullanıcılar tarafından önem düzeyi yüksek olarak ifade edilen bir diğer özelliktir. Tek Tek işlem yapmak hızlı bir operasyon içerisinde çok zaman alacağ 1 için ve maddi hatalara sebep olabileceğinden dolayı özellikle geliş sayılarının en fazla olduğu yüksek sezonda çok tercih edilmemektedir. Kullanıcıların tek tek veri girip, güncelleme yapmasından ziyade toplu işlemler yapan ekranlar, monitörler ve hesaplama araçları kullanışlı veri işlem araçlarındandır ve seyahat acentası çalışanları tarafından talep edilmektedirler. Her gün onlarca otelden gelebilecek fiyat indirimleri, otellerin oda kontenjan sayıları ve opsiyon günlerinde değişiklik yapmaları gibi bildirimler seyahat acentası çalışanlarının günlük işleri arasında çok zaman alan konulardır. Üstelik satışa hızlıca yansıtılması gerektiği için hızlı bir şekilde veri tabanına işlenmesi gerekir. Bu gibi bilgi düzenlemeleri için enformasyon sistemleri içerisinde tek tek yapılan işlemleri toplu olarak bir seferde yapabilecekleri özel tasarımlı menüler bulunabilir( toplu işlem ekranı olarak adlandırılabilirler), bu işlem ekranları zaman tasarrufu sağlamak için kullanılırlar ve tek tek vakit alan giriş işlemlerini kullanıcıların daha kolay bir şekilde, doğru ve hızlı olarak yapılabilmektedir. Bu şekilde çalışabilecekleri fonksiyonların olması kullanıcıların memnun olmalarını sağlayacaktır.

Turizm sezonunda fiyatlamayı etkileyen birkaç nedenden birisi devletin yakıt fiyatları üzerindeki vergi revizesi olabilmektedir. Olası artış ve azalışlar taşıma firmalarının hizmet maliyetlerinde sıçramalar yaratabilir. Bu değişikliklerden kaynaklı olarak taşıma firması hizmet fiyat listelerini hızlınit şekilde değiştirmesi gerekebilir. Bu durumda bu bilginin iletildiği bir seyahat acentasında mevcut kontrat fiyat listelerinde düzenleme yapmaları gerekli olacaktır. Kullanılan enformasyon sisteminde ihtiyaç duyulan toplu işlem ekranı ve hesaplama araçları veya listeleme ekranları var ise kullanıcı kısa zamanda düzenleme ve kontrollerini yapacaktır, ancak herhangi biri eksik olduğunda veya işlem esnasında sorun yaşar ise burada eğitim-teknik destek talepleri olabilir. İhtiyaç anında bu talebi karşılayabilen firma, eğer sorunu çözebiliyor ise kullanıcılarında verdikleri bu hizmet için memnuniyet yaratacaklardır.

Enformasyon kalitesi, kullanıcının sistemle olan iletişimini doğrudan etkileyen ve bu yüzden sistem üzerindeki kullanıcının tatminini ve kullanıcının sistemi kullanma eğilimini etkileyen bir kriterdir. Anketimize katılan kullanıcıların çalıştıkları seyahat acentalarında kullandıkları enformasyon sistemlerinin kalitesini ölçmek için kullanılan EK1-Sistemin doğru bilgi 
üretmesi ifadesi ve EK3-Sistemin ürettiği raporların güvenilir olması ifadelerini yer almıştır. Bu ifadelerin katılımcılarımızdan en yüksek önem ve performans puanları aldıkları ve ÖPA Matrisinde I.Hücre: "Korunması Gerekenler" bölümünde yer aldıkları görülmektedir. Kullanılan sistemlerin bu konuda performansları açısından hizmet aldıkları bilişim firmalarının verdikleri hizmetlerin devamlılığını sağlamaları önerilebilir. Seyahat Acentası çalışanları için enformasyon sistemine girilen kontrat fiyatlar1, aksiyon fiyatlar1, kontenjan-release sayıları gibi verilerin herhangi bir zamanda raporlaması yapılırken en güncel olarak çalıştıkları ekranda veya rapor çıktıları ile alınırken doğru bir şekilde görüntülenmesi çok önemlidir. Acentalar rezervasyonlar sisteme girilirken acentadaki en son güncel veriye göre sistemin kontrol yapması ve kullanıcıları limit aşımlarında uyarması, doluluk tablolarında doğru bilgi vermesi gibi pek çok işlemde sistemin sunduğu bilginin doğru olduğunu bilmek ve sistemden aldıkları tüm raporlarda sisteme güvenmek istemektedirler. EK2-Sistemden alınan bilginin açık ve anlaş1ır olması ifadelerine kullanıcıların verdiği önem değerleri ve performans değerleri ortalaması yüksek çıkmıştır. Enformasyon sistemlerinin daha fazla kullanılması açısından bu fonksiyonlar da önemlidir.

Operasyon destek sistemlerinin kullanıcısı olan seyahat acentası çalışanlarının yüksek önem değeri verdikleri bu ifadeler için kullandıkları sistemleri değerlendirdiklerinde yüksek performans değeri atamış olmalarından ötürü ÖPA matrisimizde 1. hücreye denk gelen EK1Sistemin doğru bilgi üretmesi, EK2-Sistemden alınan bilginin açık ve anlaşılır olması, EK3Sistemin ürettiği raporların güvenilir olması, SK3-Sistemin işim için ihtiyaç duyulan özellik ve fonksiyonlara sahip olması, HK1-Sistem ile ilgili ihtiyaç duyulan anda teknik destek alabiliyor olmak ve HK5-Sistem ile ilgili yetkin ve tecrübeli insanlardan destek alabiliyor olmak ifadeleri için bilişim firmalarının sundukları hizmetlerin korunması ve devamlılığı gerekmektedir.

Hizmet Kalitesi ölçeğimizde yer alan 5 kriteri hem önemlilik hem de kullandıkları sistemin performansı değerlenmesi için kullanıcılarımıza sunduğumuzda gelen değerlendirmelere göre HK3 ve HK2 ifadelerimiz önem-performans matrisinde II. Hücre-Yoğunlaş1lmas1 gerekenler bölümüne denk gelmiştir buna göre bilişim firması ve/veya destek hizmeti veren firmanın sistem ile ilgili hızlı ve yeterli destek verme konusunda yoğunlaşması, kendi performansının düşüklügünün nedenlerine eğilerek, düzeltmek ve performans artış1 sağlamak için neler yapılabileceği hakkında çalışma yapılması önerilebilir.

HK2-Sistem ile ilgili yeterli destek alabiliyor olmak, program kullanıcısı olan acenta çalışanlarının ihtiyaç duydukları anda kendi hizmet sağlayıcı firmalarından istemiş oldukları destek hizmetini alıp almadıkları noktasında önemli bir kriterdir. Yeterlilik teknik destek ve eğitim destek başlıklarında olabilir ve kullanıcı aslında programda varlığını bildiği bir takım özelliklerin nasıl kullanılacağı ile ilgili yardıma ihtiyaç duymaktadır. Bunun yanında kullanıcının sistemden aldığı sonuçlar ile ilgili tereddütleri var ise, doğruluk kontrolü ya da olası bir hatada yazılımsal düzeltme gereksinimi olduğundan desteğe ihtiyaç duyabilmektedirler. Her iki türlü de kullanıcının beklentisinin karşılanması sorun oluşturan eksikliğin giderilmesi ile olur. Burada kullanıcılara eğitim desteği verilmesi önerilebilir, kısa bilgilendirme yeterli olabilir veya hata düzeltmesi olabilmektedir.

HK2-Sistem ile ilgili hızlı destek alabiliyor olmak ifadesi de kullanıcılarımızdan 4,68 önem değeri almıştır ve ihtiyaç duyulan destek noktasında sistem sağlayıcı firmanın ne kadar hızlı dönüş yaptığı önem kazanmaktadır. Geç yapılan dönüşlerde sorunun cevaplanması kullanıcıda tatmini yaratmaktan ziyade, geç kalınması nedeniyle oluşabilecek zararlarda büyük memnuniyetsizlik doğabilmektedir. Soruların en kısa zamanda cevaplanması, sorun oluşturan konuların alternatif önererek çözülmesi veya olmayan bir fonksiyon için yazılım geliştirmesi yapılarak programa eklenmesi gibi olabilir. Asıl önemlisi tüm bunların kısa zamanda yapılıyor olmasının seyahat acentasında kullanıcılar için önemli olduğu görülmektedir. 
Diğer tarafta seyahat acentalarında hızlı olmak çok önemlidir ve çalışılan operasyon destek sistemi de hızlı ise akışkan bir faaliyet yürütmek mümkün olmaktadır. Kullanılan enformasyon sistemi yavaş çalıştığında, sıklıkla donmalar yaşanıyor, ihtiyaç anında raporlamalar uzun sürüyor ise bunlar çalışanlar için problem yaratabilmektedir. Sistem ne kadar hızlı çalışıyor ve hızlı sonuç veriyor ise seyahat acentasında iş üretimini hızlı yapmak zorunda olan kullanıcılar için bu memnuniyet yaratacaktır. Bu neden ile SK2-Sistemin hızlı olması ifadesinde kullanıcıların yüksek önem değeri vermesi yoğun bir turizm operasyonu ve çalışanlar açısından anlamlıdır ve 2 . Hücreye denk gelmesi destek firmasının bu konularda daha fazla çalışma yapması gerektiği anlaşılmaktadır.

Kullanılan operasyon destek sisteminde ihtiyaç nedeniyle yeni bir özellik sorulduğunda kullanıcılar ilk etapta sistemde arzu edilen özellik var mıdır bakacaklardır, yok ise aradıkları özelliği karşılayan ikame bir fonksiyon mevcut mudur bilgi almak için kendilerine eğitim ve teknik destek hizmeti sağlayan bilişim firması ile irtibata geçerek bu özelliği sorup, bilgi alabilirler. Eğer yok ise yeni bir özellik olarak kısa zamanda programa eklenebilir mi şeklinde talepte bulunulabilir. Enformasyon sistemi geliştiren bilişim firmaları ve destek hizmetini veren aracı kurumlar bu tarz sorular veya yazılım geliştirme istekleri ile her turizm sezonunda karşılaşmaktadırlar. Bu firmaların turizm sezonunda oluşabilecek bir ihtiyaca yönelik duyarlılık göstermesi beklenir. Enformasyon sistemlerinin güncellenerek, talepleri karşılar duruma gelmesi önemli bir özellik olabilir ancak çalışmamızda SK7-Sistemin yeni talep ve koşullara uyarlanabilecek esnekliğe sahip olması ifadesi ÖPA analizine baktığımızda 3. Hücre: Düşük öncelikler alanında yer almaktadır. Önem değeri düşük olması anketi yaptığımız acenta kullanıc1larının kullandıkları operasyon destek sistemlerinden bu konu hakkında yüksek beklentisi olmadığını bize göstermektedir.

Sistem kalitesi ölçeğimizde yer alan maddelerden SK12- Sistemin diğer yazılımlar ile entegrasyon kabiliyetinin olması anketimizde 4,51 önem değeri almıştır, bu değer ile matriste diğer kriterlerin arasında düşük öncelikliler alanında yer almaktadır. Ancak acenta çalışanları kullandıkları programların diğer sistemlerle entegre olmasına neden bu oranda bir önem değeri atamışlardır bunu biraz irdelemek gerekir. Birçok nedenle bir enformasyon programını diğer bir enformasyon program 1 ile entegrasyon yapmak isteyebilir. Mevcut sistemde eksik bir fonksiyon vardır ve başka bir enformasyon sisteminde bunu tamamlayacak özellikler var ise bu özellikleri kazanabilmek için entegrasyon yapılabilir. Örneğin bir incoming acentası yeni bir tur operatörü ile çalışmaya başladığı zaman operatör tarafından kullanılan enformasyon sistemi ile kendi kullandıkları operasyon destek sistemi rezervasyon datasını otomatik aktarabilmek için birbirine entegre edilebilir mi bunun araştırmasını yaparlar. Entegrasyon işlemleri taraflardan birinin diğer sistem verilerini kendi sistemine tanıtabilmek için geliştireceği ara modüller veya özel yazılımlar ile yapılabilmektedir.

SK10-Sistemin işletmedeki farklı bölümlerden gelen bilgiyi bütünleştirmesi ve SK11Sistem kullanımının karar alma becerisini arttırması ifadeleri ÖPA matrisinde 3. hücrede çıkmıştır, düşük seviyede performans görülmesine rağmen bu hizmetler için bilişim firmalarına performans artışı tavsiyesinde bulunmuyoruz çünkü kullanıcılar bu ifadelere 1 ve 2 . hücredeki kriterler kadar önem atamamış oldukları görülmektedir. Bu hücrede olacak performans artışının Kullanıcı memnuniyetine olumlu tesir edeceğini söyleyemeyiz. 1 ve 2 . hücredeki hizmetlerin performans artışı için çaba harcanması daha fazla kullanıcı memnuniyetine dönüşebileceği öngörülebilir.

Sistem kalitesi ölçeğinde yer alan SK9-Sistemin işteki verimliliği artırması ve enformasyon kalitesi ölçeğinde yer alan EK4-Sistemin sağladığı bilginin iyi düzenlenmiş olması ifadelerine kullanıcıların verdiği önem değerleri düşük çıktığı görülmektedir. Ancak performans değerleri ortalaması yüksek çıkmıştır. Her iki ortalamaya göre ÖPA matrisinde 4. Hücreye olası aşırılıklar 
hücresine denk geldiği görülmektedir. Önemlilik değeri verilecek bir bulgu olmamasına rağmen bilişim firmalarının bu hizmetlerinde aşırılık gösterdiği durumdur. Burada gösterilen çabanın müşteri memnuniyetine pozitif yansıyacağını ifade edemeyiz.

\section{Yazar Notu}

Bu makalemiz Ocak 2019'da jüriye sunumu yapılmış olan ve onaylanan "Seyahat Acentalarında Kullanılan Enformasyon Sistemlerinin Başarısının Kullanıcı Perspektifinden İncelenmesine Yönelik Bir Araştırma" başlıklı tezden çıkarılarak genişletilmiştir.

\section{KAYNAKÇA}

Akgün A. (2012). Seyahat Acentalarında Veri Madenciliği: Antalya Bölgesinde Bir Uygulama, Yayımlanmış Yüksek Lisans Tezi, Akdeniz Üniversitesi Sosyal Bilimler Enstitüsü, Antalya 2012.

Albayrak T. \& Caber M. (2011). "Önem-Performans Analizi: Destinasyon Yönetimine Dair Bir Örnek". Ege Akademik Bakaş Dergisi 11/4 (2011) 627-638.

Alberty S. \& Mihalik B. (1989). "The Use of Importance-Performance Analysis As An Evaluative. Technique in Adult Education". Evaluation Review 13/1 (1989) 33-44.

Büyüköztürk Ş. (2002). Sosyal Bilimler İçin Veri Analizi El Kitabı. Ankara 2002.

Cengiz F. \& Kantarcı K. (2013). “Üçüncü Yaş Turistlere Yönelik Turistik Ürün Önem-Performans Analizi”. Uluslararası Alanya İşletme Fakültesi Dergisi 5/2 (2013) 29-35.

Chan P. \& Cheung P.(2005). Relevant Attributes in Assessment For Design Features of Indoor Games Halls: The Application of Importance-Performance Analysis. Doctorate dissertation, Indiana University, Indiana, U.S.A. 2005.

Chen C. W. D. \& Cheng C. Y. J. (2009). "Understanding consumer intention in online shopping: A respecification and validation of the DeLone and McLean model". Behaviour \& Information Technology 28/4 (2009) 335-345.

Churchill J. \& Gilbert A. (1979). "A Paradigm for Developing Better Measures of Marketing Construct". Journal of Marketing Research 16/1 (1979) 64-73.

Cidral W. A., Oliveira T., Di Felice M. \& Aparicio M. (2018). "E-learning success determinants: Brazilian empirical study". Computers and Education 122 (2018) 273-290.

Çizel B. (2005). İşletme Stratejileri ile Enformasyon Sistem Stratejilerinin Uyumu (Stratejik Uyum) ve Stratejik Uyumun Antalya Yöresindeki Konaklama İşletmelerinde Araştırılması. Yayımlanmış Doktora Tezi, Akdeniz Üniversitesi Sosyal Bilimler Enstitüsü. Antalya 2005.

Davis F. D. (1989). "Perceived Usefulness, Perceived Ease of Use, and User Acceptance of Information Technology". MIS Quarterly 13/3 (1989) 319-340.

DeLone W. H. \& McLean E. R. (1992). "Information systems success: the quest for the dependent variable". Information Systems Research 3/11 (1992), 60-95.

Delone W. H. (2003). "The DeLone and McLean model of information systems success: a ten-year update". Journal of Management Information Systems 19/4 (2003) 9-30.

DeLone W. H. \& McLean E. R. (2016). "Information Systems Success Measurement". Foundations and Trends in Information Systems 2/1 (2016) 1-116.

Dolinsky A. L. (1991). "Considering the Competition in Strategy Development: An Extension of Importance-Performance Analysis". Journal of Health Care Marketing 11/1 (1991) 31-36.

Doll W. J. \& Torkzadeh G. (1988). "The Measurement of End-User Computing Satisfaction". MIS Quarterly 12/2 (1988) 259-274.

Elliot S., Li G. \& Choi C. (2013). "Understanding service quality in a virtual travel community environment". Journal of Business Research 66/8 (2013) 1153-1160.

Ennew C., Reed Gv. \& Binks M. (1993). "Importance Performance Analysis and the Measurement of Service Quality". European Journal of Marketing 27/2 (1993) 57-70.

Evans M. \& Chon K. (1989). "Formulating and Evaluating Tourism Policy Using Importance-Performance 
Analysis”. Hospitality Education and Research 13/3 (1989).

Gable G. G. Sedera D. \& Chan T.(2003). "Enterprise Systems Success: A Measurement Model”. ICIS 2003 Proceedings 48 (2003) 576-580.

Hair J., Anderson R. E., Tatham R. L. \& Black W.C. (1998). Multivarate data analysis, Fifth Edition, RaiPrentice Hall Inc, New Jersey 1998.

Hawes J. M. \& Rao C. P. (1985). "Using Importance-Performance Analysis to Develop Health Care Marketing Strategies" Journal of Health Care Marketing 5/3 (1985) 19-25.

Hema N. \& Samuel S. (2011). "Importance-Performance Analysis to determine Service Quality of a Restaurant Service-an Empirical Study". Advances in Management 4/2 (2011) 52-57.

Joseph M., Albright D., Stone G., Sekhon Y. \& Tinson J. (2005). "Importance-performance Analysis of UK and US Bank Customer Perceptions of Service Delivery Technologies". International Journal of Bank Marketing 23/5 (2005) 397-413.

Lwoga E. (2014). "Critical success factors for adoption of web-based learning management systems in Tanzania". International Journal of Education and Development using ICT 10/1(2014).

Marjanovic U., Delić M., \& Lalic B. (2016). "Developing a model to assess the success of e-learning systems: Evidence from a manufacturing company in transitional economy". Information Systems and e-Business Management 14/2 (2016) 253-272

Markus L. M., Axline S., Petrie D. \& Tanis C. (2003). "Learning from Adopters'Experiences with ERP: Problems Encountered and Success Achieved”. Journal of Information Technology 15 (2000), 245-265.

Martilla J.A. \& James J. C. (1977). “Importance-Performance Analysis”. Journal of Marketing 41/1 (1977) 77-79.

Matzler K., Bailom F., Hinterhuber H. H., Renzl B. \& Pichler J. (2004). “The Asymmetric Relationship between Attribute-level Performance and Overall Customer Satisfaction: A Reconsideration of the Importance-Performance Analysis". Industrial Marketing (2004).

Nunnally J. C (1978). Psychometric Theory. New York 1978.

Ortinau D. J., Bush A. J., Bush R. P. \& Twible J. L. (1989). “The Use of Importance-Performance Analysis for Improving the Quality of Marketing Education: Interpreting Faculty-Course Evaluations". Journal of Marketing Education 11/2 (1989) 78-86.

Özkan S. \& Bilgen S. (2003).’Bilişim Sistemleri Değerlendirme Modeli ve Üç Örnek Olay İncelemesi”. Enformatik Enstitüsü Orta Doğu Teknik Üniversitesi 2003.

Özkan S. (2005). “All Together Now: Merging Information Technology Quality and Other Business Performance Management frameworks". The Journal of Information Technology Management 18/3 (2005) 16-20.

Özkan S. (2006). “A Process Capability Approach to Information Systems Effectiveness Evaluation”. The Electronic Journal of Information Systems Evaluation 9/1 (2006) 7-14.

Parasuraman A., Zeithaml V. \& Berry L. (1988). "SERVQUAL: A Multiple-Item Scale for Measuring Consumer Perceptions". Journal of Retailing 64/1 (1988) 12-40.

Petter S., DeLone W. \& McLean E. (2008). "Measuring Information Systems Success: Models, Dimensions, Measures, and Interrelationships". European Journal of Information Systems 17/3 (2008) 236-263.

Pitt L., Watson R. \& Kavan C. (1995). "Service Quality: A Measure of Information Systems Effectiveness". MIS Quarterly 19/2 (1995) 173-187.

Rai A., Lang S. S. \& Welker R. B. (2002). “Assessing the Validity of is Success Models: an Empirical Test and Theoretical Analysis". Information System Research 13 (2002) 50-69.

Seddon P., Graeser V. \& Willcocks L. (2002). "Measuring Organizational IS Effectiveness: An Overview and Update of Senior Management Perspectives". The Database for Advances in Information Systems 33/2 (2002) 11-28.

Shannon C. E. \& Weaver W. (1949). The mathematical theory of communication. Urbana, IL: University of Illinois Press 1949.

Ultav E. E. (2010). Bilgi Sistemlerinin İşletmeler için Stratejik Önemi ve Başarısının Ölçülmesi. Yayımlanmamış Yüksek Lisans Tezi, Marmara Üniversitesi 2010. 